\title{
CONSTRUCTION OF THE CALENDAR TIMESCALE FOR LAKE WIGRY (NE POLAND) SEDIMENTS ON THE BASIS OF RADIOCARBON DATING
}

\author{
$\mathrm{N}$ Piotrowska $^{1} \cdot \mathrm{I}_{\mathrm{Hajdas}^{2}} \bullet \mathrm{G}$ Bonani $^{3}$
}

\begin{abstract}
A radiocarbon chronology of lake sediments deposited in Lake Wigry during the Last Glacial and Holocene periods provided the basis for calendar age-depth modeling. Various fractions (organics and carbonates) were dated and the results were subjected to critical analysis. The dates affected by reservoir effects as well as outlying data were excluded, and the non-linear age model was developed based on 13 ages. The statistical tools used for construction of the models include the Bayesian analysis, applied for calibration of ${ }^{14} \mathrm{C}$ dates with regard to stratigraphical position of the samples, and generalized additive models (GAM).
\end{abstract}

\section{INTRODUCTION}

Radiocarbon dating is commonly used to construct timescales of various Late Pleistocene and Holocene climatic records. Dating of lake sediments, which often provide excellent evidence of climatic changes, requires preliminary determination of material present in a particular sediment, which determines the strategy for sampling, measurement, and age-depth model construction. The age of a sediment sample should reflect the time of its deposition, and the most important issue is to identify this fraction of sediment, which would provide reliable results if present in sufficient quantity.

The main objective of this study is the construction of a calendar timescale for the sediments deposited in the southern part of Lake Wigry (Słupiańska Bay), NE Poland. The core WZS/03, recovered in 2003, was subjected to multidisciplinary paleoenvironmental research. For the presentation and interpretation of results, the calendar timescale, as described in this work, is used, e.g. for lithology (Rutkowski et al. 2007), pollen (Kupryjanowicz 2007), and Cladocera analysis (Zawisza and Szeroczyńska 2007).

\section{THE STUDY AREA}

Lake Wigry, one of the largest $\left(21.2 \mathrm{~km}^{2}\right)$ and deepest (mean depth $15.8 \mathrm{~m}$ ) lakes in Poland, is located in northeastern Poland, in the area of Suwałki Lakeland $\left(54.09^{\circ} \mathrm{N}, 23.03^{\circ} \mathrm{E}\right.$; Figure 1). Wigry National Park also includes 41 lakes in the region. Lake Wigry itself has a complex origin, with some parts being furrow type and some morainic type. Lake bathymetry, as well as the coastline, is relatively complex and divided into several main basins by underwater shallows. The surrounding area was shaped during the Baltic Glaciation, which peaked between 24,000 and 18,500 cal BP. During this time, the northern part of the present-day Wigry National Park was covered by ice, while the southern part was the area where glacial material accumulated. All of the Wigry National Park lakes were formed by retreating glaciers (Marks 2002).

Lake Wigry is mainly supplied with water from 2 rivers (Czarna Hańcza and Wiatrołuża)—which have their inflows in the northern part of the lake-and some minor watercourses from nearby lakes (Bajkiewicz-Grabowska 1992). The underground inflow, mostly in the southern part of the lake,

\footnotetext{
'Silesian University of Technology, Institute of Physics, Department of Radioisotopes, Krzywoustego 2, PL-44-100 Gliwice, Poland. Corresponding author. Email: natalia.piotrowska@polsl.pl.

${ }^{2}$ Ion Beam Physics, Paul Scherrer Institute; ETH Zurich, 8093 Zurich, Switzerland.

${ }^{3}$ Institute for Particle Physics, ETH, 8093 Zurich, Switzerland.
} 

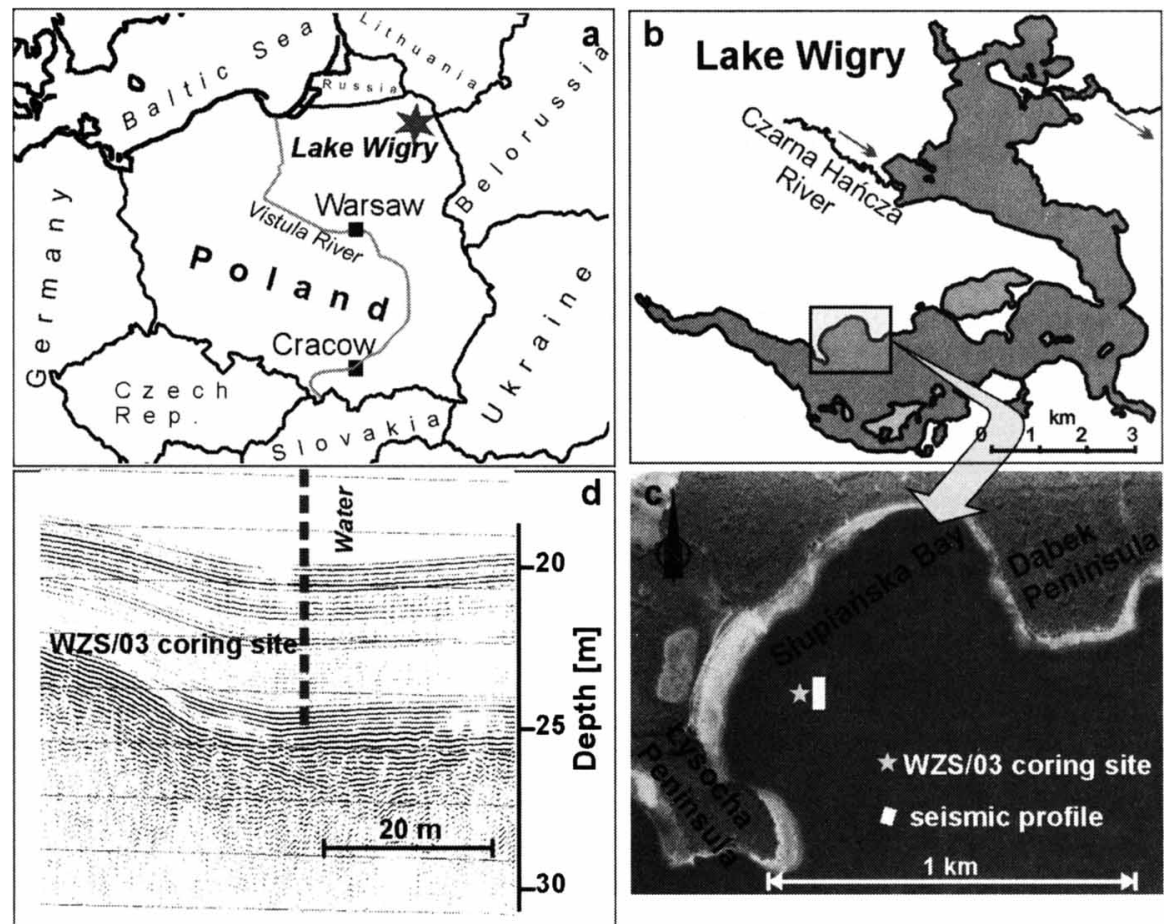

Figure 1 Location of Lake Wigry (a), Słupiańska Bay (b), the coring site (c), and a seismic profile (d) in the vicinity (Rutkowski et al. 2002b).

might also contribute considerably to the water budget. The only outlet of the lake is through the Czarna Hańcza River, though the main loss of water is due to evaporation.

The water supplying the lake is rich in dissolved calcium carbonate as a result of the presence of numerous calcareous pebbles in the surrounding postglacial bedrock. Therefore, the lake water is characterized by a high concentration of calcium carbonate, and consequently, Lake Wigry sediments are mostly carbonate-organic formations (carbonate gyttjas), characteristic of the deep areas, and almost pure carbonate (lake chalk) occurring in the littoral zone. Geological research on the Lake Wigry sediments is described by Rutkowski et al. (2002a,b, 2003), who classified the facies on the basis of seismoacoustic investigations. The lake water varies from eutrophic in the northern part to mesotrophic southern basins, including also Słupiańska Bay. More detailed water chemistry data are included in Stawecki et al. (2003) and Rutkowski et al. (2007).

\section{METHODS}

\section{Coring}

The drilling WZS/03 was performed in July 2003 using a Więckowski corer. The coring location was in the deepest part (18.2 m water depth) of the southern part of the lake, in Słupiańska Bay (Figure 1). The site was chosen based on previous seismic analysis (Figure 1c,d; Rutkowski et al. $2002 \mathrm{~b}$ ), which showed that the location was characterized by undisturbed sedimentation (Rutkowski et al. 2007). 


\section{Core Lithology}

The sediments of Słupiańska Bay constitute mainly carbonate gyttja with calcium carbonate content reaching up to $90 \%$; the remaining fraction is organic matter (Rutkowski et al. 2002a). The 5.3-mlong WZS/03 core was collected; a detailed lithological study as well as geochemical investigations carried out for WZS/03 core are presented by Rutkowski et al. (2007). Lithological investigations of the core revealed several units, characteristic for post-glacial Polish lakes. In the uppermost section, the sediments are classified as dark-gray carbonate gyttja and from $0.86 \mathrm{~m}$ gradually turn to brighter lake chalk, followed by dark-gray gyttja in the depth range of 4.2-5.0 $\mathrm{m}$. The bottom part of the core (5.0-5.3 m) contains dark, sandy lake mud with low $\mathrm{CaCO}_{3}$ content, comprising also plant macrofossils and an admixture of sand and gravel.

\section{Laboratory Preparation}

The sediments of Słupiańska Bay provide very interesting material from the point of view of ${ }^{14} \mathrm{C}$ investigations. Carbonate as well as organic fractions are a suitable source of carbon, and it is relatively easy to obtain pure $\mathrm{CO}_{2}$ for ${ }^{14} \mathrm{C}$ measurements. As part of the present study, the ${ }^{14} \mathrm{C}$ concentration in 22 organic and 16 carbonate samples has been measured. Immediately after recovery, the 8-cm-diameter core was subdivided into 5-cm-thick samples. During the sampling, several larger organic remains (like wood or reed pieces) and moss have been picked out and collected for AMS ${ }^{14} \mathrm{C}$ dating. For most organic samples, the dating was possible only via accelerator mass spectrometry (AMS) because of the small mass of the samples, while all carbonates were dated using gas proportional counting (GPC). The lists of samples and results are given in Tables 1 and 2.

The flow chart (Figure 2) illustrates the preparation procedure applied to most of the Lake Wigry sediment samples. The carbonates were decomposed with $2 \%$ hydrochloric acid, and the obtained $\mathrm{CO}_{2}$ purified and transferred to the conventional GPC in the Gliwice Radiocarbon Laboratory (Pazdur et al. 2003). A small amount of $\mathrm{CO}_{2}$ was subsampled for stable carbon isotope measurements at UMCS (Lublin, Poland). From the bottom of the core, the material of high organic content was collected, including peat, small wood fragments, roots, and other unidentified plant remains (WZS/03/ $526-528 \mathrm{~cm}$ ). Total organic carbon content of this sample allowed for ${ }^{14} \mathrm{C}$ measurements by means of the GPC technique; however, in later studies the dating was also performed on small wood pieces picked out from this mixture (WZS/03/526-528 cm D; see Table 1).

Separation and preparation of nearly all macrofossil, pollen, and alkali-soluble (SOL) samples, as well as AMS measurements, have been carried out at the ETH/PSI AMS facility in Zurich, Switzerland. All the samples were combusted and graphitized according to the standard procedures applied in the ETH laboratory (Hajdas et al. 2004). Measurements of ${ }^{14} \mathrm{C}$ concentration were carried out on the 6MV AMS system (Bonani et al. 1987). Pretreatment and graphitization of 2 samples (WZS/03/ $468 \mathrm{~cm} \mathrm{G}$ and WZS/03/526-528 cm D) were done in the AMS Gliwice Radiocarbon Laboratory (Goslar and Czernik 2000) with subsequent AMS measurements in the Poznań Radiocarbon Laboratory (Goslar et al. 2004).

All organic samples were carefully decalcified. After sieving at $250 \mu \mathrm{m}$, the coarse fraction was examined under a binocular microscope and the terrestrial macrofossil fragments were picked out following the procedure described by Hajdas (1993). Obtained samples included fossils typical for sediments of the eastern European climatic zone, such as birch nut and scale, fragments of willow leaves, pine needles, and periderm. Standard acid-alkali-acid (AAA) treatment was subsequently applied. 


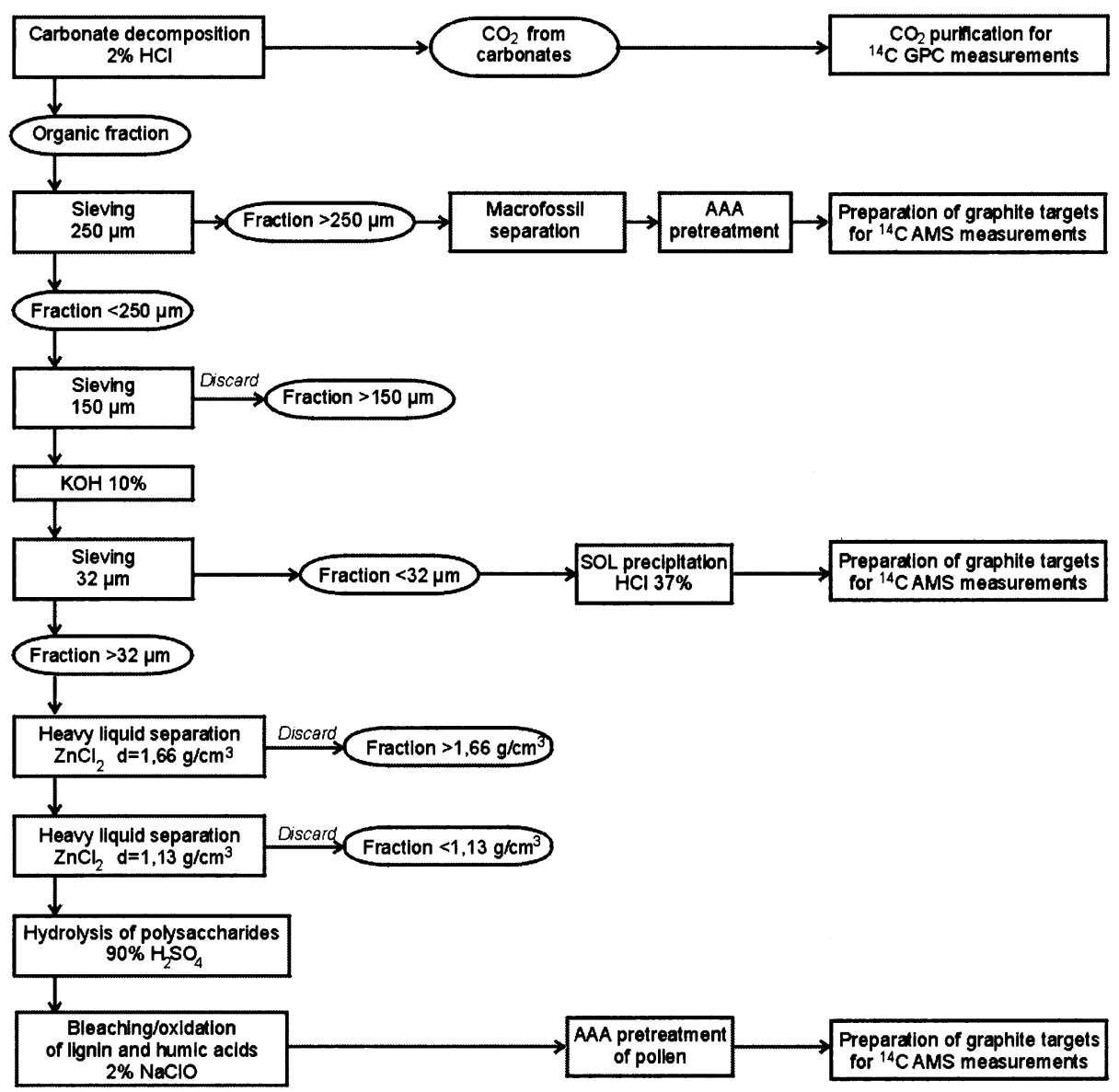

Figure 2 Flow chart of the sample preparation applied for Lake Wigry sediments

Pollen was extracted via sieving and heavy liquid separation, then the polysaccharides as well as lignin and humic acids were removed. For pollen, the same separation procedure and evaluation of sample purity were followed as for that of pollen from Lake Baikal sediments (Piotrowska et al. 2004). The effect of each step of the treatment was controlled under a binocular microscope. For Lake Wigry sediments, there was no need to apply hydrofluoric acid because the sparse mineral grains were easily removed during sieving. The steps of particular importance for high purity of the extracts were $32-\mu \mathrm{m}$ sieving and heavy liquid separation. The samples obtained were composed mostly of pine pollen with some spruce grains and an infinitesimal number of other organic particles.

\section{RESULTS}

\section{Results of Radiocarbon Dating}

All results of measurements are summarized in Table 1 (for organic samples) and Table 2 (carbonates) and presented versus depth in Figure 3. As expected, the ${ }^{14} \mathrm{C}$ ages of carbonates have proved to be affected by high apparent age, ranging from a few hundred up to $1500 \mathrm{yr}$. Preliminary isotopic studies by Pawlyta et al. (2004) of recent sediments of Lake Wigry allowed an estimation of $2000 \pm 280 \mathrm{yr}$ for this effect. Similar alteration observed for the alkali-soluble fraction (SOL) may 


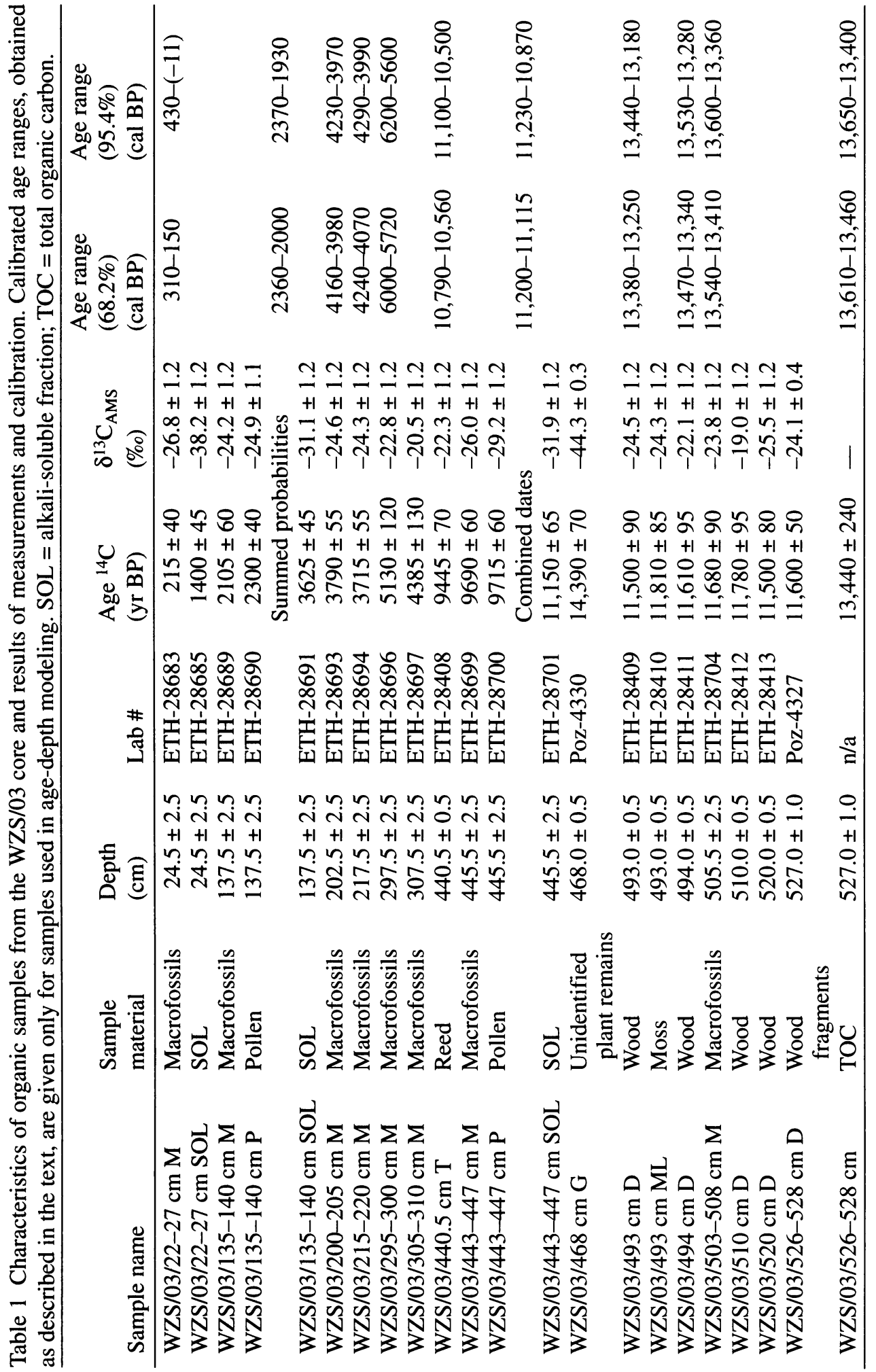


suggest that this fraction comprises decomposed organic material that had incorporated carbon dissolved in lake water. Furthermore, the ages of total organic carbon from the bottom of core (WZS/ 03/526-528 cm) and of unidentified plant material from the depth $468 \mathrm{~cm}(\mathrm{WZS} / 03 / 468 \mathrm{~cm} \mathrm{G})$ are significantly older, which could be explained by the reservoir effect or by redeposition processes. For total organic carbon (TOC) samples, the first explanation seems fairly probable, especially when the TOC age is compared with the date obtained for wood pieces separated from this sample, which is in quite good agreement with the remaining data. A similar, although not so distinct, effect is observed for moss samples from the depth $493 \mathrm{~cm}$ (WZS/03/493 cm ML). However, the plant material, discovered as a several-mm-thick layer, is even older than a carbonate sample from the same depth, also seeming to be an outlier. It could be interpreted as an occurrence of a short disturbance event, but the measured $\delta^{13} \mathrm{C}$ of $-44.3 \%$ o for this plant material is anomalously low, suggesting some perturbations in graphite target preparation or measurement. For the reasons described above, the ages obtained for these 3 samples were not taken into consideration when the age-depth model was built.

Table 2 Results of dating for bulk carbonate samples from the WZS/03 core using conventional techniques. All ${ }^{14} \mathrm{C}$ ages are corrected for isotopic fractionation.

\begin{tabular}{|c|c|c|c|c|}
\hline Sample name & $\begin{array}{l}\text { Lab \# } \\
\text { Gd- }\end{array}$ & $\begin{array}{l}\text { Depth } \\
(\mathrm{cm})\end{array}$ & $\begin{array}{l}\delta^{13} \mathrm{C}_{\mathrm{VPDB}} \\
(\% \circ)\end{array}$ & $\begin{array}{l}{ }^{14} \mathrm{C} \text { age } \\
\text { (yr BP) }\end{array}$ \\
\hline $\mathrm{WZS} / 03 / 22-27 \mathrm{~cm} \mathrm{~W}$ & 15607 & $24.5 \pm 2.5$ & -4.64 & $1487 \pm 85$ \\
\hline $\mathrm{WZS} / 03 / 38-43 \mathrm{~cm} \mathrm{~W}$ & 15615 & $40.5 \pm 2.5$ & -5.3 & $1619 \pm 45$ \\
\hline $\mathrm{WZS} / 03 / 50-55 \mathrm{~cm} \mathrm{~W}$ & 15617 & $52.5 \pm 2.5$ & -5.17 & $1447 \pm 80$ \\
\hline WZS/03/92-98 cm W & 15619 & $94.0 \pm 2.0$ & $-5.53^{a}$ & $2703 \pm 90$ \\
\hline $\mathrm{WZS} / 03 / 185-190 \mathrm{~cm} \mathrm{~W}$ & 12611 & $187.5 \pm 2.5$ & -5.89 & $4116 \pm 70$ \\
\hline $\mathrm{WZS} / 03 / 195-200 \mathrm{~cm} \mathrm{~W}$ & 12612 & $197.5 \pm 2.5$ & -5.71 & $4374 \pm 55$ \\
\hline $\mathrm{WZS} / 03 / 200-205 \mathrm{~cm} \mathrm{~W}$ & 15616 & $202.5 \pm 2.5$ & -5.23 & $4515 \pm 100$ \\
\hline $\mathrm{WZS} / 03 / 215-220 \mathrm{~cm} \mathrm{~W}$ & 15625 & $217.5 \pm 2.5$ & -5.04 & $4407 \pm 95$ \\
\hline $\mathrm{WZS} / 03 / 255-260 \mathrm{~cm} \mathrm{~W}$ & 12613 & $257.5 \pm 2.5$ & -7.06 & $5389 \pm 80$ \\
\hline $\mathrm{WZS} / 03 / 280-285 \mathrm{~cm} \mathrm{~W}$ & 12608 & $282.5 \pm 2.5$ & -4.93 & $5721 \pm 80$ \\
\hline $\mathrm{WZS} / 03 / 295-300 \mathrm{~cm} \mathrm{~W}$ & 12607 & $297.5 \pm 2.5$ & -4.81 & $6132 \pm 70$ \\
\hline $\mathrm{WZS} / 03 / 305-310 \mathrm{~cm} \mathrm{~W}$ & 15622 & $307.5 \pm 2.5$ & -5.05 & $6365 \pm 110$ \\
\hline $\mathrm{WZS} / 03 / 415-418 \mathrm{~cm} \mathrm{~W}$ & 15624 & $416.5 \pm 1.5$ & -5.05 & $8814 \pm 155$ \\
\hline WZS $/ 03 / 443-447 \mathrm{~cm} \mathrm{~W}$ & 15620 & $445.5 \pm 2.5$ & -3.17 & $10,558 \pm 125$ \\
\hline WZS $/ 03 / 463-468 \mathrm{~cm} \mathrm{~W}$ & 17256 & $465.5 \pm 2.5$ & -3.17 & $13,968 \pm 580$ \\
\hline WZS $/ 03 / 493-498 \mathrm{~cm} \mathrm{~W}$ & 15621 & $495.5 \pm 2.5$ & -2.19 & $13,839 \pm 260$ \\
\hline
\end{tabular}

${ }^{\mathrm{a}} \delta^{13} \mathrm{C}$ for sample from depth $92-98 \mathrm{~cm}$ approximated on the basis of adjacent measurements.

Age reversals shown around 200 and $300 \mathrm{~cm}$ and for the bottom samples imply that more outliers should be removed, but the choice of outliers is not a straightforward procedure at this stage, and this problem was solved by Bayesian analysis incorporated into the calibration of a sequence of dates (Buck et al. 1991) using OxCal v 3.10 software (Bronk Ramsey 1995, 2001) and the IntCal04 calibration curve (Reimer et al. 2004).

\section{Sequence Calibration and Outlier Detection}

Macrofossil and pollen samples from depths of 137.5 and $445.5 \mathrm{~cm}$ were dated twice. Both materials represent terrestrial organic fractions; the results obtained for macrofossils and pollen from the $445.5 \mathrm{~cm}$ depth are in perfect agreement (confirmed by $t$ test for the independent samples), which 


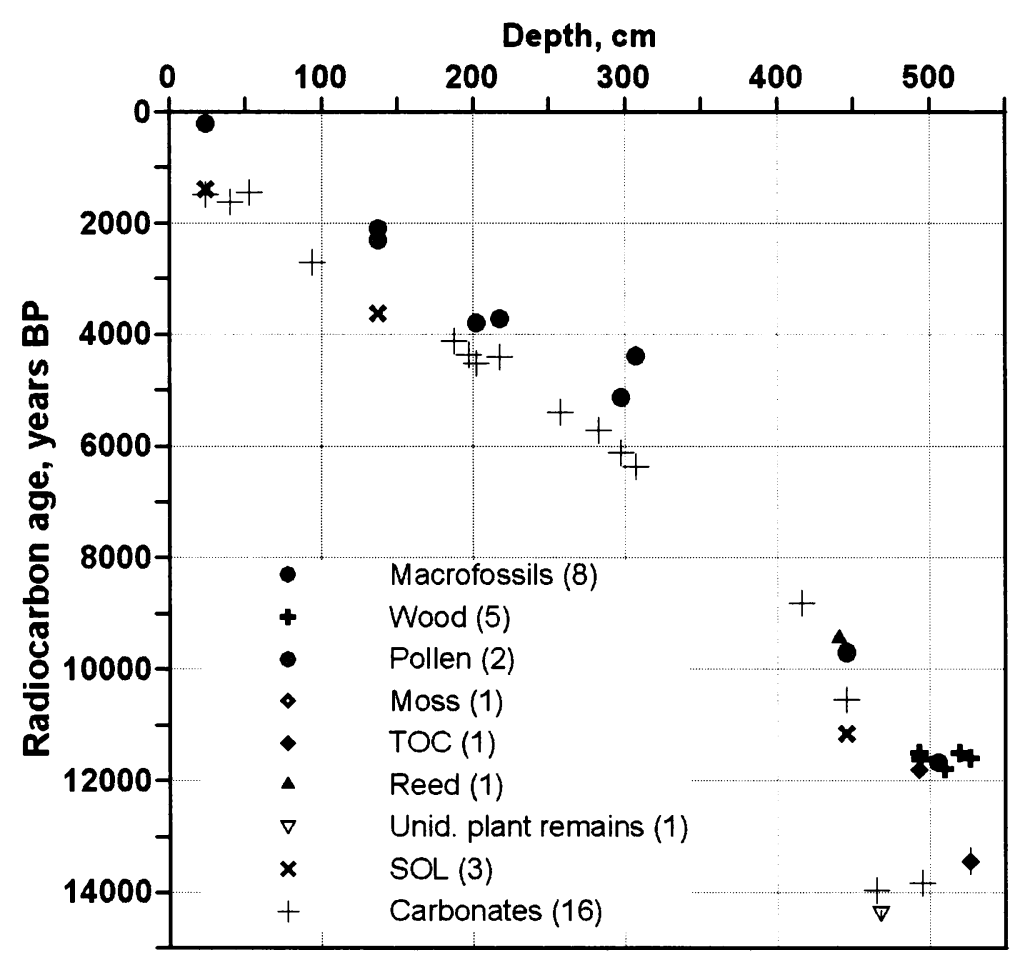

Figure $3{ }^{14} \mathrm{C}$ ages of all samples from the WZS/03 core on the depth scale

permits combination or a weighted average of the dates. Conversely, the dates from $137.5 \mathrm{~cm}$ are not consistent in terms of statistical tests, although they are quite close. Averaging of such incoherent dates could lead to confusing conclusions and illusionary precision, and it was not possible to exclude unambiguously one of them. For these samples, the probabilities of calendar ages were summed, resulting in more reliable but wider calibrated age ranges (and, furthermore, larger uncertainty in the age-depth model).

In the OxCal v 3.10 program, the "agreement index" allows the evaluation of results from the Markov chain Monte Carlo (MCMC) modeling. An agreement between assumed chronological order and data is obtained when the agreement index $A$ approaches $60 \%$ or more. The first results of calculations obtained for the WZS/03 sequence were characterized by an extremely poor overall $A$ (14.2\%) as well as a low $A$ for several dates, as was expected, while age reversals have occurred. For 2 samples around $300 \mathrm{~cm}$, the younger date (ETH-28697, 4385 \pm 130 ) was suspected to be an outlier because of its extremely small sample mass (only $0.23 \mathrm{mg} \mathrm{C}$ ) and absence of age reversal for carbonate samples from the same depths. Accepting such a young age would increase the reservoir effect to $1800 \mathrm{yr}$ (see Figure 3). Similar considerations for samples around $200 \mathrm{~cm}$, and quite high $A$ values for these samples (both $\sim 80 \%$ ), lead to the conclusion that none of them is an outlier. A more complicated situation arises in the case of 4 dates on wood from the bottom part of the core. Here, several trials to remove only 1 date have not given satisfactory results; thus, in the final analysis the oldest and the youngest have been removed. The conclusive results of calibration as described above are presented in Figure 4. The overall agreement index reached $99 \%$ and the $A$ for all samples exceeds $60 \%$. The results of calibration for samples selected for construction of the agedepth model are listed in Table 1 as age ranges of $68.2 \%$ and $95.4 \%$ probability. 


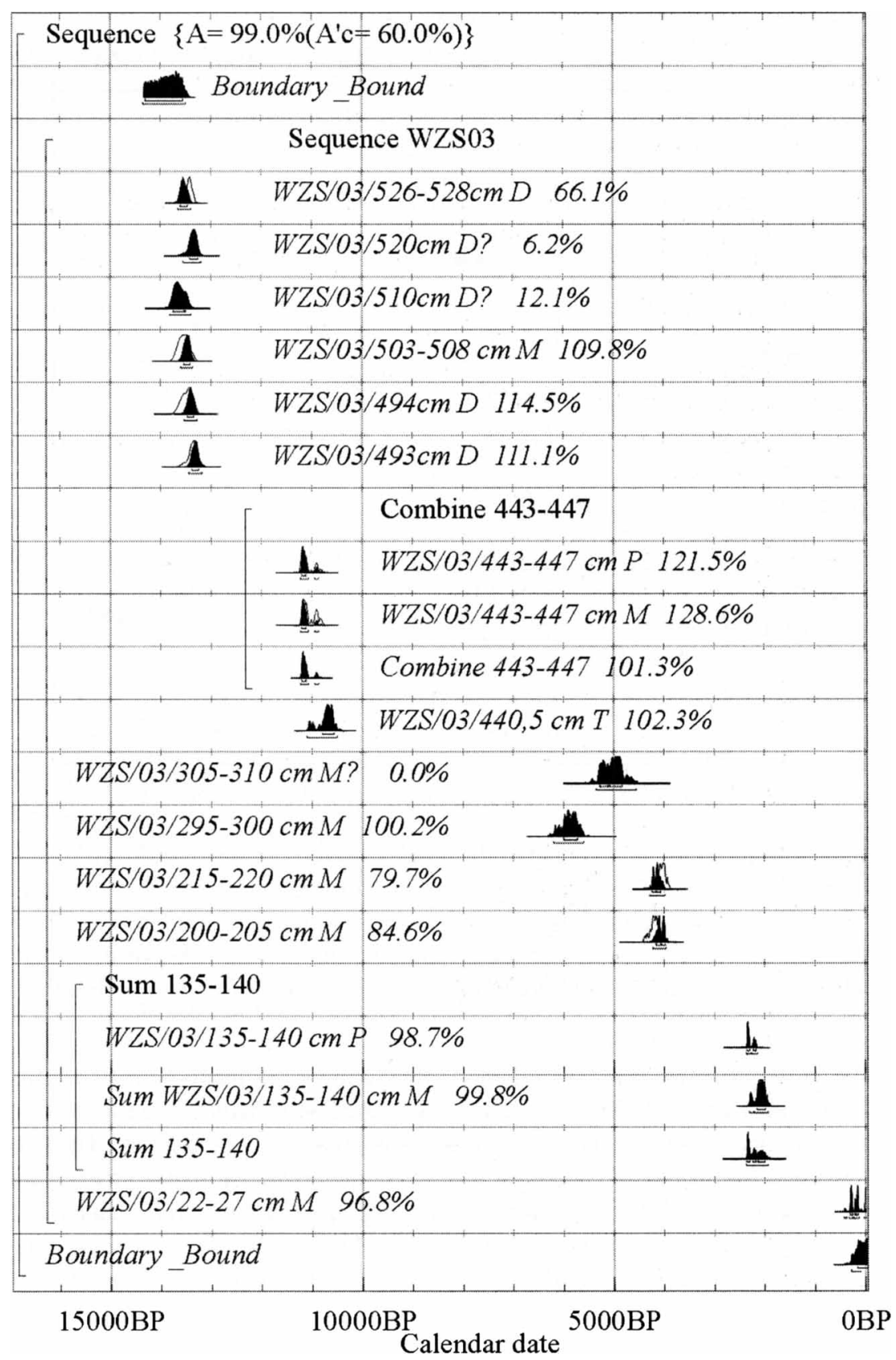

Figure 4 Results of Bayesian calibration of ${ }^{14} \mathrm{C}$ dates for the WZS/03 core as described in the text. Numbers near sample names show agreement indexes; outliers are denoted by question marks.

\section{GAM Modeling}

The calibrated ${ }^{14} \mathrm{C}$ ages (midpoints of $95.4 \%$ ) of samples plotted versus depth do not show linear dependence (see Figure 5), which makes the assumption about constant sedimentation rate not justified, at least for the whole sequence. For purposes of age model construction, the non-linear regression method has been used to produce generalized additive models (GAMs). First introduced 
by Hastie and Tibshirani (1990, 1995), GAMs are a statistical tool used for non-linear fits to experimental data and for predicting the system response for specified conditions, by using smoothing techniques, most often spline functions. GAMs are successfully applied in many fields like ecology and environmental sciences (e.g. Brosse and Lek 2000; Bellido et al. 2001), as well as one of the tools in analyses of large data sets in economics by data-mining techniques.

In the present work, the GAMs were used for depth as an independent variable and age as a system response, taking advantage of its most important feature: lack of assumptions about age-depth relationship. Use of GAMs for age-depth modeling was first proposed by Birks and Heegaard (2003) and developed by Heegaard et al. (2005). The calculations were carried out according to the procedure described in the latter article with use of the functions Cagedepth.fun and Cagenew.fun (Heegaard 2003) and freeware R statistical environment (R Development Core Team 2004). The aforementioned functions allow also calculations of the uncertainty of age-depth relation, taking into account not only the uncertainty of age determination but also thickness of the sample and the uncertainty of the model itself (Heegaard et al. 2005). Therefore, the application requires depth and age intervals as incoming data.

The results of modeling are presented in Figure 5 together with the data used for calculations, plotted as midpoints of $95.4 \%$ range used as a point estimator and using half of the range as an uncertainty estimator.

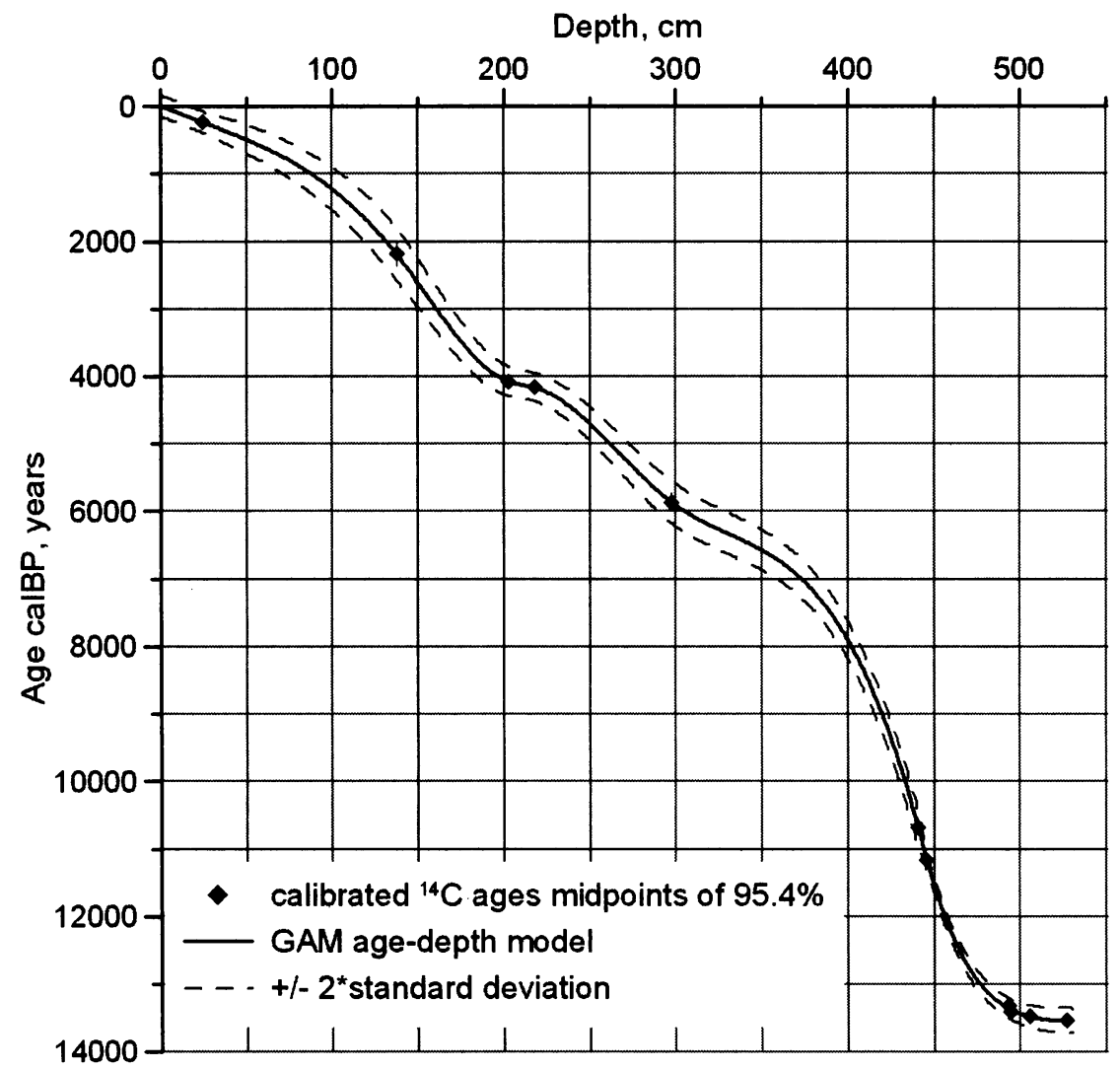

Figure 5 Age-depth model for the WZS/03 core from Słupiańska Bay, Lake Wigry, obtained via GAM modeling. 


\section{DISCUSSION AND CONCLUSIONS}

${ }^{14} \mathrm{C}$ dating of Lake Wigry sediments has provided results that enabled age-depth model construction. Application of generalized additive models (GAMs) is based on the assumption of the high reliability of data used for the modeling procedure; therefore, it requires especially critical selection of the data on which the age model is strongly dependent, which may be considered somewhat insecure. Another important feature of GAM implementation is consistent calculation of standard deviation, which includes all main sources of uncertainty in the case of dating a sediment core. The model uncertainty clearly increases in the ranges where less dates are available or the dates are less certain, and decreases in the ranges of higher-resolution data. Hence, combining careful selection of sample material and dates, sequence calibration and GAM computation seem to be an advisable approach to age-depth modeling. The main weakness of the GAM method is its assumption about Gaussian distribution of calibrated ages and consequent use of the midpoints of age range, which is obviously incorrect. Bearing in mind the low resolution of the data for the WZS/03 core as well as uncertainties of the model and the data, this approximation may be justified, and the use of another point estimator would not introduce considerable alteration of the model in this case.

The constructed age-depth model provides the basis for studies of Lake Wigry sediments and is to be used in forthcoming publications of paleoenvironmental studies. In addition to the study of carbon and oxygen isotopes carried out for the contemporary environment of Lake Wigry and its surroundings by Sensuła et al. (2006) and Pawlyta et al. (2004), future isotope investigations will include modeling of lake-level change on the basis of ${ }^{14} \mathrm{C}$ measurements in carbonates as well as climatic interpretation of stable carbon and oxygen isotope composition of carbonates from the WZS/03 core.

\section{ACKNOWLEDGMENTS}

AMS ${ }^{14} \mathrm{C}$ dating has been carried out during the scientific stay of $\mathrm{N}$ Piotrowska, funded in the framework of the EU-project GADAM Centre of Excellence (EVK2-CT-2002-80008) coordinated by A Pazdur. $\delta^{13} \mathrm{C}$ measurements for carbonate samples were kindly performed by $\mathrm{S}$ Hałas from the Institute of Physics, Maria Curie-Skłodowska University, Lublin, Poland. The authors would like to also acknowledge J Rutkowski and K Król from the AGH Academy of Sciences and Technology (Kraków) and Wigry National Park for cooperation in coring and receiving material for the present study. Application of GAM for age-depth modeling was a subject included in an ESF-funded HOLIVAR training course "Quantitative climate reconstruction and data-model comparisons," Ghent, Belgium, July 2004, in which N Piotrowska participated. This work was performed at the AMS facilities, jointly operated by the Swiss Federal Institute of Technology, Zurich, and Paul Scherrer Institut, Villigen, Switzerland.

\section{REFERENCES}

Bajkiewicz-Grabowska E. 1992. Warunki odpyłwu i wymiana wód $w$ jeziorach [Discharge and exchange conditions of water in lakes]. In: Zdanowski B, editor. Jeziora Wigierskiego Parku Narodowego. Stan eutrofizacji $i$ kierunki ochrony. PAN. Kom. Naukowy "Człowiek i środowisko" Zesz. Nauk. 3:25-34. In Polish.

Bellido JM, Pierce GJ, Wang J. 2001. Modelling intraannual variation in abundance of squid Loligo forbesi in Scottish waters using generalised additive models. Fisheries Research 52(1-2):23-39.
Birks HJB, Heegaard E. 2003. Developments in agedepth modelling of Holocene stratigraphical sequences. PAGES Past Global Changes News 11:7-8.

Bonani G, Beer J, Hofmann H, Synal H-A, Suter M. Wölfli W, Pfleiderer C, Kromer B, Junghans C, Münnich KO. 1987. Fractionation, precision and accuracy in ${ }^{14} \mathrm{C}$ and ${ }^{13} \mathrm{C}$ measurements. Nuclear Instruments and Methods in Physics Research B 29(1-2):87-90.

Bronk Ramsey C. 1995. Radiocarbon calibration and analysis of stratigraphy: the OxCal program. Radiocarbon 37(2):425-30. 
Bronk Ramsey C. 2001. Development of the radiocarbon program. Radiocarbon 43(2A):355-63.

Brosse S, Lek S. 2000. Modelling roach (Rutilus rutilus) microhabitat using linear and nonlinear techniques. Freshwater Biology 44(3):441-52.

Buck CE, Kenworthy JB, Litton CD, Smith AFM. 1991. Combining archaeological and radiocarbon information: a Bayesian approach to calibration. Antiquity 65(249):808-21.

Goslar T, Czernik J. 2000. Sample preparation in the Gliwice Radiocarbon Laboratory for AMS ${ }^{14} \mathrm{C}$ dating of sediments. Geochronometria 18:1-8.

Goslar T, Czernik J, Goslar E. 2004. Low-energy ${ }^{14} \mathrm{C}$ AMS in Poznań Radiocarbon Laboratory, Poland. $\mathrm{Nu}$ clear Instruments and Methods in Physics Research B 223-224:5-11.

Hajdas I. 1993. Extension of the radiocarbon calibration curve by AMS dating of laminated sediments of Lake Soppensee and Lake Holzmaar [PhD dissertation]. Zurich: Eidgenössische Technische Hochschule. $149 \mathrm{p}$.

Hajdas I, Bonani G, Thut J, Leone G, Pfenninger R, Maden C. 2004. A report on sample preparation at the ETH/PSI AMS facility in Zurich. Nuclear Instruments and Methods in Physics Research B 223-224:267-71.

Hastie TJ, Tibshirani RJ. 1990. Generalized Additive Models. Boca Raton, USA: Chapman and Hall/CRC. $352 \mathrm{p}$.

Hastie TJ, Tibshirani RJ. 1995. Generalized additive models. In: Kotz S, editor. Encyclopedia of Statistical Sciences. New York: John Wiley \& Sons.

Heegaard E. 2003. The estimation of the relationship between calibrated age and depth in palaeorecords [WWW document]. http://www.uib.no/bot/qeprg/ Age-depth.htm. Accessed 26 January 2005.

Heegaard E, Birks HJB, Telford RJ. 2005. Relationships between calibrated ages and depth in stratigraphical sequences: an estimation procedure by mixed-effect regression. The Holocene 15(4):612-8.

Kupryjanowicz M. 2007. Postglacial development of vegetation in the vicinity of the Wigry Lake. Geochronometria 29:53-66.

Marks L. 2002. Last Glacial Maximum in Poland. Quaternary Science Reviews 21(1-3):103-10.

Pawlyta J, Pazdur A, Piotrowska N, Poręba G, Sikorski J, Szczepanek M, Król K, Rutkowski J, Hałas S. 2004.
Isotopic investigations of uppermost sediments from Lake Wigry (NE Poland) and its environment. Geochronometria 23:71-8.

Pazdur A, Fogtman M, Michczyński A, Pawlyta J. 2003. Precision of ${ }^{14} \mathrm{C}$ dating in Gliwice Radiocarbon Laboratory. FIRI programme. Geochronometria 22:27-40.

Piotrowska N, Bluszcz A, Demske D, Granoszewski W, Heumann G. 2004. Extraction and AMS radiocarbon dating of pollen from Lake Baikal sediments. Radiocarbon 46(1):181-7.

$\mathrm{R}$ Development Core Team. 2004. The R project for statistical computing [WWW documentation and software]. http://www.R-project.org.

Reimer PJ, Baillie MGL, Bard E, Bayliss A, Beck JW, Bertrand CJH, Blackwell PG, Buck CE, Burr GS, Cutler KB, Damon PE, Edwards RL, Fairbanks RG, Friedrich M, Guilderson TP, Hogg AG, Hughen KA, Kromer B, McCormac G, Manning S, Bronk Ramsey C, Reimer RW, Remmele S, Southon JR, Stuiver M, Talamo S, Taylor FW, van der Plicht J, Weyhenmeyer CE. 2004. IntCal04 terrestrial radiocarbon age calibration, 0-26 cal kyr BP. Radiocarbon 46(3):1029-58.

Rutkowski J, Król K, Krzysztofiak L, Prosowicz D. 2002a. Recent sediments of Lake Wigry (Bryzgiel Basin). Limnological Review 2:353-62.

Rutkowski J, Rudowski S, Pietsch K, Król K, Krzysztofiak L. 2002b. Sediments of Wigry Lake (NE Poland) in the light of high-resolution seismic (seismoacoustic) survey. Limnological Review 2:363-71.

Rutkowski J, Król K, Krysztofiak L, Prosowicz D. 2003. Recent sediments of Wigry Lake (Szyja Basin), NE Poland. Limnological Review 3:197-203.

Rutkowski J, Król K, Szczepańska J. 2007. Lithology of the profundal sediments in Słupiańska Bay (Wigry Lake, NE Poland) - introduction to interdisciplinary study. Geochronometria 29:47-52.

Sensuła B, Böttger T, Pazdur A, Piotrowska N, Wagner R. 2006. Carbon and oxygen isotope composition of organic matter and carbonates in recent lacustrine sediments. Geochronometria 25:77-94.

Stawecki K, Zdanowski B, Dunalska J. 2003. Seasonal changes in phosphorus concentrations in the waters of Lake Wigry. Limnological Review 3:217-22.

Zawisza E, Szeroczyńska K. 2007. The development history of Wigry Lake as shown by subfossil Cladocera. Geochronometria 29:67-74. 